\title{
The State of Elementary and Secondary Education in Iowa in 1900
}

\author{
KEACH JOHNSON
}

Principal W. O. Riddell of Des Moines West decided to break precedent in his presidential address to the Iowa State Teachers' Association on December 26, 1900. "I trust I shall not be thought to have departed too far from the established custom of this occasion if I fail to catalogue all of the evils of the public schools; and if for once I dwell upon their glories," Riddell told the association. No teacher could be unmindful of the weaknesses of public education, but the turn of the century was an appropriate time to pause to remind Americans of the uniqueness of their educational system and to take stock of its remarkable accomplishments. The unprecedented intellectual and material growth in the nineteenth century had been due above all else to education, Riddell asserted; and the most powerful force in education, although by no means the only one, had been the growth of public schools. "The American school system, imperfect as it is, is the most stupendous monument to civilization ever reared in one century," Riddell declared. The system's physical dimensions alone were impressive. They included 250,000 schoolhouses built at a cost of a half billion dollars. The schools were attended by an army of pupils and teachers larger than the armed hosts of all Europe: some sixteen million children and young people, ranging in age from kindergarten to high school, and a half million teachers. ${ }^{1}$

Riddell had high praise for the two newest parts of the American public school system, the kindergarten and the high

1. Proceedings of the Iowa State Teachers' Association, 1900, 14 (hereafter cited as ISTA, Proceedings). 
school. "Of all the contributions to education in the nineteenth century, none has been more fruitful than the kindergarten," Riddell observed. Introduced only recently into the United States from Europe, the kindergarten was the smallest component of the public school system, including only two hundred thousand children and nine thousand teachers. Yet the kindergarten had already demonstrated its worth in shaping the mental, moral, and physical growth of children, in stimulating their imagination and inventiveness, and in teaching them habits of cleanliness, neatness, and politeness. "Our five thousand kindergartens planted in the hearts of our cities and towns are but a promise of what we shall soon have," Riddell predicted. ${ }^{2}$

The high school, like the kindergarten, was a product of the nineteenth-century push for universal education, Riddell continued. Although the high school had now become a constituent part of the American public school system, it had had to struggle for recognition and acceptance, and its role was still in doubt. High schools had benefited from the "stimulating, uplifting influences" of colleges and universities, Riddell believed, but high schools had also suffered from too much college influence, notably in the widespread misconception that their principal function, like that of the academies they had largely supplanted, was to prepare young people for college. Fortunately, the danger of college domination, although still a threat, was passing; "the wisest and most liberal college men" were coming to realize that the high school's true mission was to meet community needs rather than college admissions requirements. The character of the high school must be determined not by outside influences but by the aspirations, needs, and resources of the community that supported it. Whether the high school maintained a two-, four-, or five-year program, whether it emphasized the classics or science and technology, were questions for the community to decide. $^{3}$

Riddell also was encouraged by the schools' growing recognition that they must try to educate the whole child. That required schools to broaden and personalize their programs and methods. There was a movement to beautify and sanitize school

2. Ibid., 14-15.

3. Ibid., 16. 
buildings and grounds in order to refine the behavior and taste of the pupils as well as to protect their health. There was also increasing emphasis on subjects that would build character; educational leaders emphasized the teaching of art, history, literature, and music as a means of "exalting character above knowledge, the child above the book." Boys and girls with character had a foundation to build on; if they lacked character, class rank and a diploma meant little. Educators had always known this to be true, but only now were they beginning to act on it. "We are just becoming interested in the boy himself," Riddell said. "This interest is manifesting itself in the kindlier relation between pupil and teacher, and in the milder discipline of the schools."4

Riddell's focus was national rather than local, but the trends he outlined were at work in Iowa's school system, although in varying degrees. Iowa had been a state for only fiftyfour years in 1900 . The western half of the state, in fact, was not settled until after the Civil War and had barely emerged from the frontier stage of development at the turn of the century. Iowa settlers were interested in education, but they were necessarily preoccupied with the pressing problems of settlement, with establishing homes, farms, and businesses. "That any attention whatever has been given to schools is to the credit of these pioneers," commented City Superintendent A. W. Merrill of Waverly in 1899. "From this pioneer stage we are just emerging," added Merrill, "and now, if the opportunity be seized, much of the energy and enterprise beginning to be set free from more material pursuits can be utilized in the development of a wiser and broader educational policy."

Iowans spent $\$ 9,028,919$ in 1900 to operate 13,861 schools which employed 28,789 teachers to instruct 373,474 pupils. The great majority of these schools were elementary schools comprising the first six to eight grades, but lowa's public school system also included a sprinkling of kindergartens and high schools. "The time must come when the kindergarten will be recognized as an essential part of the school training of children," John F. Riggs, the state superintendent of public instruction,

4. Ibid., 15-16.

5. Ibid., 1899, 130. 
forecast in 1905. "The movement is slowly, but surely, gaining ground." By 1905, twenty-six cities and towns in Iowa maintained 90 kindergartens taught by 132 teachers, and the State Normal School in Cedar Falls had organized a kindergarten department to meet the increasing demand for kindergarten teachers. The department, which included a training school, opened at the beginning of the academic year, 1904-5, and was warmly received by parents and students in Cedar Falls. "The Training School Kindergarten has been crowded to its utmost capacity," reported Harriet Elizabeth Gunn, the director of the kindergarten department. "At times there have been as many as twenty children waiting to come in." The kindergarten training school also aroused much public interest, attracting three thousand visitors during its first year of operation. ${ }^{6}$

The high school got off to a slow and uncertain start in Iowa as in other states, but it had built a solid base of popular support by 1900 . High schools originated in Iowa to fill the gap between the common schools and the colleges which the private academies and the preparatory departments of the colleges were unable to fill. Critics objected that high schools benefited the few at the expense of the many and thus were an unwarranted addition to the public school system. The mounting demand for greater local opportunities for higher education proved to be irresistible, however, and the "peoples' colleges" multiplied rapidly at the turn of the century. "Indeed no educational doctrine seems more firmly established in this state and throughout the country today than that our youth are entitled to both a common school training and a thorough high school training at public expense," State Superintendent Riggs commented in 1905. "But this sentiment has crystallized only recently and the development of the high school from a very feeble institution to its present importance has been witnessed within the teaching experience of educators yet in the prime of life." Noting that progress had been particularly rapid during the last decade, Riggs added that Iowa now had 560 high schools offering two or more years of work. Of these,

6. Iowa Department of Public Instruction, Report (hereafter cited as IaDPI, Report), in Iowa Legislative Documents (hereafter cited as Ia Leg Doc), 1906 , vol. 5, pt. $1,6-7,10,43-46$. 
301 were four-year high schools, 170 had three-year programs, and 89 offered two years of secondary studies. ${ }^{7}$

Closely allied to the rise of the kindergarten and the high school was the movement of educators in Iowa and other states to broaden as well as lengthen public education. Leading Iowa educators realized that the formal learning of the past was too narrow, "too exclusively intellectual," to meet the demands of the present: the schools needed to expand their goals and programs if they were to meet public expectations. In 1899 the Iowa State Teachers' Association called for the "symmetrical" education of children, for the "complete and harmonious" development of their mental, moral, and physical powers. Elaborating its goals two years later, the association resolved that all American children ought to be taught to read intelligently, to spell correctly, to write legibly, and to use the English language correctly; to know enough arithmetic to succeed in business and enough history to be proud of their heritage as American citizens; to possess sufficient command of the manual arts to perform skilled labor; and to develop a sound character based on the principles of right, justice, temperance, obedience to law, and neighborliness. ${ }^{8}$

IOWA'S PUBLIC SCHOOLS were representative of the progress being made in American public education, but they were also representative of the system's shortcomings. The professional meetings of lowa teachers and administrators dealt far more with problems than progress. In Iowa as in the other states, local control of the schools, lack of state or federal guidelines or standards, helter-skelter growth, and the tumultuous economic and social changes attending industrialization and urbanization all combined at the turn of the century to produce confusion and uncertainty regarding the goals, methods, and structure of public education. ${ }^{9}$

Of particular concern to educators was the backwardness of rural schools, which offered the only educational opportunity available to most young Americans in the predominantly rural

7. ISTA, Proceedings, 1904, 22-23; ibid., 1905, 20, 21, 22.

8. Ibid., 1898, 9; ibid., 1899, 10, 11; ibid., 1901, 11.

9. Theodore R. Sizer, Secondary Schools at the Turn of the Century (New Haven, 1964), xi-xiii, 6-14, and passim. 
society of the time. The National Education Association resolved in 1904 that the "Rural School and its problems should receive the solicitous care" of the association as long as more than half of the American people were rural. There must be "no forgotten masses" anywhere in the United States, the association declared. Of the 548,852 young Iowans enrolled in public schools in 1898 , 377,340 (65 percent) were in ungraded schools, which were generally one-room country schools taught by a single teacher. Of the 13,861 public schools in Iowa in 1900, 12,615 were ungraded; the remaining 1,246 were graded schools located mainly in cities and towns. ${ }^{10}$

Iowa school leaders warned that rural schools had not kept pace with urban schools, that they were not meeting the needs of rural communities, and that they were not likely to do so under existing conditions. Some country schools were excellent, but most were ill-housed and ill-equipped, poorly taught, irregularly attended, isolated, and unsupervised except for an occasional visit by the county superintendent. "When you stop to think, you know that our boast of a low per cent of illiteracy is without foundation in many of our rural communities," E. C. Lillie, the county superintendent of Buchanan County, told a gathering of county superintendents in 1900 . The mere fact that people were able to read and write their names did not necessarily mean that they were literate. "Count up the number of [school] districts in your county where it is difficult to secure men with sufficient education to fill the offices acceptably, and you cannot fail to be convinced that the rural schools are not meeting the requirements of the twentieth century, although they have been grinding away under the present laws for fifty years," said Lillie. Stating that half of the rural teachers in Iowa were deficient in some respect-in ability, scholarship, or professional training - Lillie declared that a school system that handicapped future generations by imposing on them such incompetent teachers was "little less than criminal" and ought to be abolished. ${ }^{11}$

"Something must be done for our country schools," declared Charles E. Shelton, president of Simpson College and

10. ISTA, Proceedings, 1904, 10-12; IaDPI, Report, in Ia Leg Doc, 1900, 2 : 70; ibid., 1906, vol. 5, pt. 1, 6-7, 12.

11. ISTA, Proceedings, $1900,69-70$. 
president of the Iowa State Teachers' Association in 1902, in his presidential address to the association. He believed that "threefourths" of the teaching in the country schools of Iowa was "absolutely worthless" and that "an equal proportion" of the money spent on rural education in the state was "absolutely thrown away." According to Shelton, everyone with experience teaching young people educated in rural schools knew that they were "practically untaught." There were, of course, a few "brilliant ones" who learned despite their disadvantages, but the "great majority of the young men and women who come to our normal schools and our institutes, who come into the business walks of life trained only in the rural schools, can hardly read, can cipher but little, and can use the English sentence not at all with accuracy." Neither the teachers nor the county superintendents were to blame for this sorry state of affairs, said Shelton; both were underpaid and overburdened. The fault lay in public unawareness of the problems of rural education plus the general conservatism of Iowans in dealing with educational matters. ${ }^{12}$

Compounding the educational disadvantages of rural youth was their limited opportunity for secondary education. Most country school districts were unable or unwilling to bear the cost of supporting a high school, so the great majority of young Iowans living in the country did not have an opportunity for secondary education unless their parents could afford to pay the tuition and other expenses involved in sending them to a private school or to a public high school outside of their district. State Superintendent Richard Barrett reported in 1899 that 70 percent of Iowa's children lived in rural school districts "remote from high schools." In 1903-4 rural parents paid \$114,000 in tuition to send 9,888 children to town and city schools: 3,932 to elementary schools and 5,956 to high schools. State Superintendent John Riggs estimated in 1905 that less than 40 percent of Iowa's school-age population lived in school districts with high schools offering two or more years of work. Yet that 40 percent furnished five-sixths of the state's high school enrollment, with the remaining 60 percent providing only one-sixth. "That is to say, of the 38,916 pupils enrolled in Iowa high schools last year [1904-5], 31,938 lived in high school districts and 6,978 lived in

12. Ibid., 1902-3, 17. 
the country." These figures did not include the large number of country boys and girls enrolled in private academies and the preparatory departments of small colleges, but even after taking these students into account, Riggs thought that the number of rural young people working at the secondary level was "relatively small."13

City schools generally were superior to country schools in Iowa as in other states. Urban children enjoyed numerous educational advantages over rural children: graded school systems, including high schools; better buildings and equipment, including laboratories and libraries; better-paid teachers with more education and experience; and closer supervision by superintendents and principals. Yet urban schools also had problems. They had grown so rapidly that there had been little time to coordinate their growth and develop coherent overall programs. High schools were new; there was little agreement as to their nature, meaning, or purpose. Lines of demarcation between elementary, secondary, and higher education were vague at best. Communities tended to add high schools indiscriminately without realizing the need to combine elementary education and secondary education into a cohesive community system. ${ }^{14}$

One of the problems of rapid growth was the tendency of urban schools to spread themselves too thin, to try to teach too many subjects. State Superintendent Henry Sabin thought that one of the weaknesses of the common (grade) schools in the large towns and cities of Iowa was an overcrowded curriculum, which resulted in superficial instruction and neglect of the fundamentals of learning. J. B. Harsh, Creston banker and state legislator, believed that the schools, especially those in large towns and cities, ought to be required to teach industrial arts, but he told the Iowa State Teachers' Association that he hesitated to recommend such legislation because the common schools, particularly those in towns and cities, were attempting to do too much already. As a result, declared Harsh, a majority of the children going through the public schools failed to gain a good grasp of the basic skills, such as arithmetic, reading, and writing. State Superintendent Richard Barrett was "thoroughly convinced"

13. IaDPI, Report, in Ia Leg Doc, 1900, 2: 73; ibid., 1906, vol. 5, pt. 2, 119; ISTA, Proceedings, 1905, 24.

14. Sizer, Secondary Schools, xi-xiii, 18-19, 29-32, 70-71, and passim. 
that the efforts of educators to enrich curricula would cause schools to neglect the basic subjects. In fact, that was already happening, said Barrett; many of the students seeking admission to institutions of higher learning in Iowa were "woefully deficient in the use of English, the elementary principles of arithmetic, and in the ability to spell our common English words and to write a legible hand." Poor preparation was widespread among students seeking entrance to the State Normal School, for example; before they could begin their professional training many of them had to be drilled in subjects that they ought to have learned in high school. ${ }^{15}$

City Superintendent C. W. Cruikshank of Fort Madison thought that the failure of public schools to provide a good foundation for higher education originated in the failure of grade schools to teach children how to study. This was due partly, Cruikshank believed, to incompetent teaching and partly to a "feverish" pursuit of new subjects and methods with a consequent overloading of the curriculum. "Careful consideration has led me to believe that we are crowding too many subjects into the grades," Cruikshank stated. The worst offenders were "the most advanced city schools," which, in order to maintain their reputation for leadership, offered algebra, geometry, literature, physics, Latin, music, and drawing in the grades in addition to the traditional common-school subjects. "Now we are not saying that much of this is not good, but it is too much," said Cruikshank. Such overloading of the curriculum plus the frenetic search for simplified methods of learning that frequently accompanied it resulted in superficiality. Children learned to skim rather than to study; they gained a smattering of knowledge of many subjects without ever learning how to master any subject. ${ }^{16}$

Unprepared to meet the demands of secondary education, many youths found the transition from grade school to high school to be too difficult and dropped out. Cruikshank believed that the high schools were also at fault; he blamed them for failing to recognize that many of the young people entering high school were unable or unwilling to meet the rigid expectations

15. IaDPI, Report, in Ia Leg Doc, 1890, 2: 73; ISTA, Proceedings, 1894, 69; IaDPI, Report, in Ia Leg Doc, 1902, 3: 23.

16. ISTA, Proceedings, 1899, 133, 134-35. 


\section{Education in Iowa}

and requirements of the high schools. The high schools had been too much inclined to believe that all students were capable of becoming scholars, that it was the high school's mission to develop the power of " 'patient thought,' " said Cruikshank, borrowing a phrase from Sir Isaac Newton. This mistaken assumption overlooked individual differences; many young people lacked the capacity for close study necessary to master the classics or mathematics. Finding the work dull and unintelligible, they dropped out. About 60 percent of those entering high school failed to graduate, Cruikshank noted. Some 70 to 80 percent of those dropping out did so the first year. More than half of those who dropped out did so because they were failing algebra or Latin. ${ }^{17}$

To remedy the dropout problem, Cruikshank advocated the elective system that many of the "best" high schools were turning to with "marked success." The elective system was more in line with the purpose of the high schools, which was to reach the greatest possible number of young people, than rigid adherence to a fixed course of study framed for the benefit of the small number of students planning to attend college. Was it reasonable, asked Cruikshank, "to bar all other doors of knowledge" because students lacked the ability or desire to learn algebra or Latin or some other required subject? The purpose of education, after all, was not to acquire specialized knowledge of a particular subject or subjects but rather to awaken and to stimulate the mind to activity " 'along some line of thought.' "18

Cruikshank's criticism of the high schools illustrates the disagreement and uncertainty of Iowans and Americans generally regarding the role of the high school in the American public school system. Iowa law authorized local school boards to maintain " 'one or more schools of a higher order, for the better instruction of all in the district prepared to pursue such a course of study," "and to establish "'graded or union schools and determine what branches shall be taught therein,' " subject to the approval of the state superintendent of public instruction. However, the General Assembly did not define the role of the high school or the nature and meaning of secondary education.

17. Ibid.

18. Ibid., 135. 
Teachers agreed that work above the eighth grade ought to be high school work but "what constitutes a high school has never been defined," State Superintendent J. B. Knoepfler reported in 1893. "Nowhere do the Iowa statutes define a high school, prescribe any conditions precedent to its organization, require a higher standard of qualifications for its teachers than is required in the elementary school, or put supervision of the course of study in the hands of any officer with power to do more than recommend," State Superintendent John F. Riggs complained in 1905. Riggs thought that the General Assembly doubtless intended that approval of high school courses of study by the state superintendent would give some uniformity to the development of high school programs. Such approval, however, "has been and still is, a dead letter," Riggs declared; the adoption of high school curricula was determined solely by local school boards. ${ }^{19}$

Operating under local control with little direction or guidance from the state and with no common standards regarding the purpose, content, or scope of secondary education, high schools in lowa as in other states were in disarray at the turn of the century. Varying widely in their programs, standards, quality of work, and size, the high schools ranged from four-year city institutions with a full complement of teachers and equipment, including laboratories and libraries, to two-year high schools of one room and one teacher in village schoolhouses of two to four rooms. State superintendents complained that they had no way to determine the amount or character of the work done in the high schools. A committee of the lowa State Teachers' Association (ISTA), appointed to study the standing of high schools and to propose uniform courses of study, reported in 1896 that it was impracticable to attempt to classify high schools because of the great diversity of their courses and requirements. Some "high schools" were high schools in name only, the committee found, doing "exactly the same kind of work that is done below the high school, paying no attention to disciplinary or secondary studies whatever except that they include certain branches in their course that are usually covered in the secondary school." At the other extreme were high schools that were too ambitious. They

19. Sizer, Secondary Schools, xi-xiii, 4-5, 18-19, 29-32, and passim; ISTA, Proceedings, 1905, 23; IaDPI, Report, in Ia Leg Doc, 1894, 2: 25; ISTA, Proceedings, 1905, 21, 23, 24. 
undertook to act like colleges, the committee stated, exceeding their "legitimate province" and endeavoring "to do such work as belongs properly to the higher education. ${ }^{20}$

THE LOW LEVEL OF WORK done in some high schools was doubtless due in considerable part to the low level of teaching; many teachers in high schools were not properly qualified to teach high-school subjects. Iowa did not yet require special preparation or certification for high-school teaching. "Hundreds of teachers" in Iowa high schools "are this winter giving instruction in the higher branches, who hold a license to teach only the common branches of study," County Superintendent Richard C. Barrett of Mitchell County told the ISTA in his presidential address in 1895. Doctors, dentists, and lawyers were not allowed to practice in fields beyond their competence, Barrett noted; the same restriction should also apply to teachers. ${ }^{21}$

During the decade from 1895 to 1905 the quality of secondary education in Iowa remained uncertain, but many high schools, especially urban ones, succeeded in raising the qualifications of their teachers. After reviewing the progress of public education in Iowa during the preceding five years, State Superintendent Barrett concluded in 1901 that there had been marked educational growth and improvement in the cities and towns, especially in the qualifications of teachers. "The high schools are now as a general rule well equipped and supplied with teachers well educated for their special work," Barrett reported. Barrett's successor, John F. Riggs, concurred in Barrett's assessment when he discussed "Iowa's High School Problem" before the ISTA in 1905. Asserting that the high schools of the state were doing much "excellent" work despite their weaknesses, Riggs stated that high school faculties were "being strengthened every year" by the influx of "trained and scholarly" teachers. Of the 1,726 teachers employed in the high schools of Iowa in 1905, 1,057 had graduated from a college, university, or normal school, while 423 more had attended college or normal school one or

20. IaDPI, Report, in Ia Leg Doc, 1890, 2: 69-72; ibid., 1894, 2: 25-26; ISTA, Proceedings, 1895-96, 9-14, 27-29, 40, 56-57, 58, 67, 118-19; IaDPI, Report, in Ia Leg Doc, 1900, 2: 43-45.

21. IaDPI, Report, in Ia Leg Doc, 1890, 2: 71-72; ISTA, Proceedings, 1895$96,27-28,42,43-44$. 
more years, the average length of attendance being 3.6 years. Most of the teachers, moreover, were experienced; 1,341 (78 percent of the total) had had experience in teaching prior to the current school year, the average length of experience being five years. ${ }^{22}$

Neither Barrett nor Riggs explained why the high schools were gaining better teachers except to note the return of prosperity and the "wonderful growth" that high schools were experiencing. ${ }^{23}$ Another influence, less visible but potent nevertheless, was the growth of the accreditation movement and the pressure that it put on high schools to raise their standards. The accreditation of high schools in Iowa was initiated by the State University of Iowa in 1873 and expanded in 1897 when the state university and the College and University Department of the ISTA agreed to cooperate in working for uniform college entrance requirements in Iowa, preparing lists of approved high schools whose graduates would be admitted to the state university and the member institutions of the College and University Department without examination, and drawing up courses of study for high schools. Administration of the program was entrusted to the Committee on Secondary School Relations, a standing committee of the ISTA's College and University Department. Working for closer relations among the state university, the colleges, and the high schools, the committee performed a variety of tasks. It sought to work out common university and college admissions policies, supervised the inspection of high schools seeking accreditation, coordinated proposed changes in college and university admissions requirements with accredited high schools, drew up courses of study for small high schools (those offering only one or two years of sec-

22. IaDPI, Report, in la Leg Doc, 1902, 3: 25; ISTA, Proceedings, 1905, 21.

23. IaDPI, Report, in Ia Leg Doc, 1902, 3: 26; ISTA, Proceedings, 1905, 21. "The increasing number of towns maintaining a high school course shows their popularity with the people," reported State Superintendent J. B. Knoepfler in 1893. "They are the colleges of the common people." High schools improved citizenship by awakening the minds of many young people who were unable to attend college. Good high schools whetted students' appetites "for a broader culture" than the high schools offered, inducing "many a young man or woman to seek collegiate training who otherwise would never have awakened to its advantages," said Knoepfler. IaDPI, Report, in Ia Leg Doc, 1894, 2: 25. 
ondary work), and lobbied the General Assembly for greater breadth and flexibility in the state certification of teachers. The committee also sought higher standards in the appointment of high-school teachers; at a meeting in 1903, for example, the committee voted to support "most heartily" the efforts of college and university inspectors to raise the qualifications of highschool teachers, who ought to be college graduates with "substantial" professional training and special preparation in the subjects they were expected to teach. ${ }^{24}$

The improvement in the qualifications of urban highschool teachers notwithstanding, "the teacher problem" remained a perennial topic of discussion at professional meetings and in professional publications. Critics lamented the limited education, lack of professional training, and inexperience of Iowa teachers. The greatest of all the problems confronting the public schools of Iowa, State Superintendent Barrett declared in 1899, was how to obtain and to keep competent teachers. Barrett's first priority was to provide qualified teachers for all of the schools in Iowa. Stressing the urgency of the teacher problem, the ISTA called on the General Assembly in 1899 to establish a second state normal school during the next biennium. The ISTA resolved that it must "impress" upon the legislature "the established principle that as long as the schools of the state are filled with teachers of very limited ability and with no special preparation for their work, we are not meeting the exigencies of the time as good citizens should." However, in the presidential address in 1900 Principal W. O. Riddell of Des Moines West told the ISTA that inadequate teacher-training facilities were not the basic cause of the teacher problem. The root of the problem, said Riddell, was the willingness of Iowans to tolerate cheap, poorly prepared teachers who could be hired for $\$ 25$ per month. ${ }^{25}$

The mounting concern and controversy over the quality of teaching in the public schools led State Superintendent Barrett to make a survey of the education of Iowa teachers in 1900 to find out how many trained teachers there were in Iowa. If the results of his investigation showed a shortage of qualified teach-

24. ISTA, Proceedings, 1904, 125-33; ibid., 1902-3, 68-69; ibid., 1903, 80-82; ibid., 1904, 118-19, 125-27, 133.

25. IaDPI, Report, in Ia Leg Doc, 1900, 2: 17; ibid., 1902, 3: 26, 33; ISTA, Proceedings, 1899, 7, 8; ibid., 1900, 17. 
ers, Barrett hoped that the evidence would add to the pressure on the General Assembly to authorize more state normal schools to train teachers. If, on the other hand, the survey revealed that Iowa had enough skilled teachers to meet its needs, an eventuality that Barrett considered unlikely, the friends of public education could turn to other vital school needs. ${ }^{26}$

Barrett asked the county superintendents to report the schooling of the teachers they had licensed in 1900: how much formal education the teachers possessed and where they had received it. Tabulating the reports, Barrett found that 22,319 men and women were licensed to teach in Iowa in 1900. Of these, 1,285 held state certificates or diplomas issued by the State Board of Educational Examiners, while 21,034 held certificates conferred by the county superintendents. About 60 percent of the teachers had some form of training beyond the common schools: they were about equally divided between those who had graduated from a broad range of accredited secondary schools, normal schools, colleges, and universities and those who had attended such institutions without graduating (see table). The other 40 percent, who were not included in the county superintendents' reports, evidently had not progressed beyond the common schools or unaccredited secondary schools; they had received, in Barrett's words, "only such scholastic instruction as is provided in the rural schools and the smaller cities and towns." 27

Barrett's survey indicated that some three-fifths of the men and women licensed to teach in Iowa in 1900 had relatively good credentials, judging by the standards of the time, while the remaining two-fifths had virtually no credentials. The investigation also revealed that some two-fifths of the Iowans preparing themselves to teach did not carry their preparation beyond the secondary level. Of the teachers who had been educated in the various kinds of schools included in Barrett's study, 43 percent had obtained their highest education in secondary schools. ${ }^{28}$

26. ISTA, Proceedings, $1900,40$.

27. Ibid., 1901, 46; IaDPI, Report, in Ia Leg Doc, 1902, 3: 17, 30-31, 12731, Appendix, "Abstract $[C]$ - Reports for 1900. Examination of Teachers," 14-15. $127-31$.

28. ISTA, Proceedings, 1901, 46; IaDPI, Report, in Ia Leg Doc, 1902, 3: 
Commenting on the results of his investigation, Barrett estimated that the high schools supplied 80 percent of the teachers coming out of the secondary schools. He urged that no one be allowed to teach in Iowa who had not pursued "a scholastic course equivalent to that given in an accredited high school," but he thought that this was about as much education as the state could require of teachers. To limit the certification of teachers only to those who had attended or graduated from a college, university, or normal school would cut the supply of teachers so drastically, Barrett stated, that most schools would be forced to close. ${ }^{29}$

Formal Education of Iowa Teachers Licensed in 1900

\begin{tabular}{|c|c|c|c|}
\hline & graduated & $\begin{array}{c}\text { attended } \\
\text { without } \\
\text { graduating }\end{array}$ & total \\
\hline State University of lowa (lowa City) & 138 & 178 & 316 \\
\hline Iowa State Normal School (Cedar Falls) & 707 & 1,515 & 2,222 \\
\hline $\begin{array}{l}\text { Iowa State College of Agriculture } \\
\text { and the Mechanic Arts (Ames) }\end{array}$ & 97 & 159 & 256 \\
\hline $\begin{array}{l}\text { Accredited academies, high schools, } \\
\text { and seminaries in lowa }\end{array}$ & 3,791 & 1,853 & 5,644 \\
\hline $\begin{array}{l}\text { Private normal schools and denominational } \\
\text { schools and colleges in lowa }\end{array}$ & 1,135 & 2,352 & 3,487 \\
\hline Institutions of higher learning outside Iowa & 499 & 559 & 1,058 \\
\hline $\begin{array}{l}\text { Total number of lowa teachers with } \\
\text { formal training beyond common schools }\end{array}$ & 6,367 & 6,616 & 12,983 \\
\hline Total with formal training unreported & & & 9,336 \\
\hline Teachers licensed to teach in Iowa in 1900 & & & 22,319 \\
\hline
\end{tabular}

SOURCES: ISTA, Proceedings, 1901, 46; laDPI, Report, in Ia Leg Docs, 1902, 3: 127-31.

The preparation of teachers in the high schools of Iowa was haphazard at best. Some people doubted that the training of teachers was a proper function of high schools. Principal Eugene Peirce of Ottumwa, who believed that the training of teachers was a necessary and proper function of high schools, surveyed teachertraining programs in the high schools of Iowa in 1900. Arguing that high schools played a major part in training teachers both nationally and locally, Peirce cited the report of William T. Harris, the United States Commissioner of Education, for the biennium, 1897-1898. Of the 89,225 students pursuing "normal" courses in educational institutions across the nation, Harris reported, 13,367,

29. ISTA, Proceedings, 1901, 47; ibid., 1902-3, 48. 
more than one in seven, were doing so in public and private high schools. Iowa's portion of the national total was 5,287 students, of whom 450, about one in twelve, were enrolled in public and private high schools. So Peirce wrote to 134 high schools in Iowa, including all of those with ten or more students in the class of 1900, asking them what courses they offered to prepare their students to teach. Of the 102 high schools replying to Peirce's letter, 57 provided no special preparation in teaching. Of the 45 high schools that did offer "one or more studies of normal nature," 32 offered "review courses in the common branches," which some of the schools described as "intentionally pedagogical," while others said that the courses were only "indirectly" pedagogical. Other schools reported that they taught two- to four-year courses designed to enable their students to earn first- or second-grade teaching certificates. Some high schools taught courses variously entitled psychology, pedagogy, or didactics which ran for a year in some cases and one semester in others. A few communities, such as Davenport, operated training schools to enable their high-school graduates to gain actual experience in teaching plus an opportunity for further academic learning. ${ }^{30}$

The training of teachers in the colleges, universities, and normal schools of Iowa in 1900 probably varied as much in content and quality as it did in the secondary schools. The line between secondary and higher education was indistinct at the time; it is likely that many of the private normal schools and denominational schools and colleges of Iowa, which formed the second largest group on Barrett's list, were secondary schools in fact if not in name. Superintendent S. H. Sheakley of Des Moines West commented in 1900 that the education offered by normal schools "as now constituted" comprised little more than a high school curriculum plus "a little practice in a training school." Sheakley thought that conditions were no better in colleges and universities, where departments of pedagogy were "securely tucked away in a corner," providing no more than "elementary knowledge of the branches to be taught."

Given the uncertain quality of the education and professional training of Iowa's teachers, it is not surprising that only a

30. Ibid., $1900,80$.

31. Ibid., 22; ibid., 1901, 46; IaDPI, Report, in Ia Leg Doc, 1902, 3: 127-31. 
relatively small number of them were able to earn first-grade certificates. The certification of teachers in Iowa was in the hands of the State Board of Educational Examiners, which issued licenses that were valid throughout the state, and the ninety-nine county superintendents, who granted certificates that were good only in the county where they were conferred. The state's standards of certification were considerably higher than those of the counties. To earn state certificates and state diplomas, which were lifelong certificates, candidates must have graduated from "good" secondary or normal schools-those whose courses of study had been approved by the board of examiners-or from institutions of higher learning approved by the board. The applicants must also have had successful teaching experience or its equivalent in pedagogical training and must pass comprehensive examinations, including the preparation of theses by those seeking diplomas, in a broad range of liberal and professional subjects. Not many Iowa teachers were able to meet these standards. From 1882-1883, when the system of state certification began, through 1900-1901, the state board of examiners issued 3,103 certificates, 348 diplomas, 287 primary certificates to teachers of the first, second, and third grades, and 3 special certificates to specialists in such subjects as drawing, music, and penmanship. (The board of examiners did not begin to issue primary certificates until $1898-1899$ and special certificates until 1900-1901.) Many of the state licenses had expired by $1900-1901$, but 1,730 state certificates and 348 state diplomas remained in force as of September 30, 1901. ${ }^{32}$

The standards of county certification varied from county to county. The General Assembly decided what subjects were to be included in the certification examinations, and the state superintendents issued guidelines in an effort to achieve as much uniformity as possible. However, the authority to issue county certificates was vested solely in the county superintendents. They prepared and graded the examinations and determined the candidates' fitness to teach. Academic standards varied widely as a result; an applicant who earned a grade of ninety and a firstgrade certificate in one county might earn no more than seventy

32. IaDPI, Report, in Ia Leg Doc, 1902, 3: 178-89; ibid., 1906, vol. 5, pt. 1, 23-24, 171-76; ISTA, Proceedings, 1903, 91-92. 
and a second-grade certificate in the next county. The system also gave free play to all of the other variables involved in individual differences. Through favoritism or carelessness, county superintendents might certify some teachers for attending a county institute, while requiring a full examination of others. To take the certification examination, applicants must pay a fee which was used to support the county's normal institute. This prompted some superintendents to attempt to swell the institute fund by issuing certificates only for three or six months in order to require teachers to take a second examination and pay another fee into the fund the county superintendents administered. Politics also entered into certification, for the county superintendency was a political office. Superintendents were chosen in general elections held every two years and were vulnerable, therefore, to pressure to certify the friends and relatives of their partisans regardless of their qualifications. Probably few county superintendents were guilty of all these malpractices, but such abuses were inherent in the existing system of county certification and were present to some extent throughout the state..$^{33}$

County superintendents issued first-, second-, and thirdgrade certificates plus kindergarten certificates and special certificates to specialists such as music teachers who taught only their specialty. To earn first-grade certificates, which lasted two years, candidates must show that they had taught successfully for thirty-six weeks and must demonstrate their scholarship by passing a written examination over the various subjects commonly taught in the schools. Second-and third-class certificates required similar examinations but were issued for shorter periods, permitted lower scores on the examination, and demanded little or no experience in teaching. Second-grade certificates were good for only one year and generally required only one term (three months) of successful teaching at most. Third-grade certificates were limited to one or two terms at the discretion of

33. IaDPI, Report, in Ia Leg Doc, 1902, 3: 13-14; ibid., 1904, 4: lxxix-lxxxi; ibid., 1906, vol. 5, pt. 1, 23-25, 26-27, pt. 2, 147-52. State Superintendent Riggs believed that political influence was no less pervasive in the certification of teachers in lowa than it was in Wisconsin, where 90 percent of the county superintendents reported in 1900 that they could not limit certification only to those they considered to be qualified because of the political pressure brought to bear on them. IaDPI, Report, in Ia Leg Doc, 1906, vol. 5, pt. 2, 148. 
the county superintendent, were not to be granted more than once or twice to the same person, and required no experience. Third-grade certificates were essentially expedient documents that were issued only when they were needed to provide enough teachers to supply schools that would be forced to close otherwise. It was generally recognized, according to State Superintendent Richard Barrett, that persons holding third-grade certificates were "not properly qualified to teach." ${ }^{34}$

The great majority of Iowa teachers held second- and thirdgrade certificates. In 1900, for example, county superintendents examined 29,671 applicants for certification (4,582 males and 25,089 females), a representative number. (They examined 29,277 applicants in $1897,29,025$ in 1898, and 30,084 in 1899). Rejecting 5,014 of the candidates, the county superintendents issued 2,917 first-grade certificates, 13,828 second-grade certificates, 7,228 third-grade certificates, 596 special certificates, and 88 kindergarten certificates, totaling 24,657 certificates granted to 21,034 persons. (The number of certificates was greater than the number of persons because some of the certificates, notably those of the third class, were limited to a few months; consequently, more than one certificate might be issued to the same individual during a year). With the addition of the 1,285 teachers who held state certificates or diplomas, there were 22,319 certified teachers in Iowa in $1900 .{ }^{35}$

The essential point that emerges from this data is that Iowa did not have enough qualified teachers to meet its needs. The public schools of the state needed some eighteen to nineteen thousand teachers per year at the turn of the century. There were enough licensed teachers to supply all of the schools in the state in 1900, but the credentials of some 30 percent of the teachers were marginal at best. ${ }^{36}$ Of the 24,657 county certificates issued in 1900 ,

34. laDPI, Report, in Ia Leg Doc, 1902, 3: 30; ibid., 1904, 4: 54-56.

35. Ibid., 1900, 2: 9; ibid., 1902, 3: 17,30-31, Appendix, "Abstract [C]," 14-15.

36. Although the above figures suggest that there was a surplus of teachers in $1900-22,319$ certified teachers for eighteen to nineteen thousand positions - the surplus existed only on paper; the supply of teachers was tight in actual practice. State Superintendent Barrett reported that the number of teachers available in 1900, including all of those with third-grade certificates, was "very little above the actual constant demand, which is increasing." laDPI, Report, in Ia Leg Doc, 1902, 3: 31. 
7,228 were third-grade certificates, and of these, 6,167 were issued to females, "presumably young girls just out of school, many of them not having completed the common school course," opined State Superintendent Barrett. Of the 21,034 individuals certified by the county superintendents in 1900 , 3,560 had had no prior experience in teaching and 4,208 had taught less than one year. ${ }^{37}$

The country schools suffered most from the shortage of qualified teachers, but the town and city schools were also hurt. School boards in the cities and larger towns generally sought to employ teachers with first-grade certificates and successful teaching experience. "There is hardly a graded school in the state, at least not in any town of 1,000 or 1,200 population, where the board of directors will employ a teacher who does not hold a firstclass certificate," State Superintendent Barrett observed. Barrett pointed out, however, that the supply of such teachers fell short of the demand; there were not enough teachers with first-grade certificates to meet the needs of the graded schools. Only 4,202 teachers had first-rate credentials in Iowa in 1900 (2,917 with first-grade certificates and 1,285 with state certificates or diplomas), some 1,600 fewer than the number needed by the graded schools, which employed about 5,800 teachers. The cities and larger towns were able to compete successfully for the limited number of highly qualified teachers available by paying higher salaries than the country schools could afford, providing better buildings and equipment, and offering cultural and recreational advantages that were not available in the rural districts. Of the 3,974 teachers employed in 134 cities and towns of Iowa during the school year, 1903-4, 719 were college or university graduates, 504 had graduated from state normal schools, 2,269 were graduates of academies, four-year high schools, or private normal schools, and all but 82 had teaching experience. ${ }^{38}$

Iowa educators agreed that the shortage of qualified teachers was the greatest single weakness of rural education. Unable to compete with urban schools for the most highly qualified teachers, rural schools were forced, in the blunt words of State Superintendent Barrett, to take "what is left." Most of the teach-

37. IaDPI, Report, in Ia Leg Doc, 1902, 3: 17, 30, Appendix, "General Summary of Statistics," 470, "Abstract [C]," 14-15.

38. Ibid., 1902, 3: 17, 31; ibid., 1906, vol. 5, pt. 2, 118. 
ers in the 12,615 ungraded rural schools of Iowa in 1900 held second- or third-grade certificates. Many of them were teenaged young people with little or no education or training beyond the district schools they had attended. Speaking of the 3,560 teachers who were certified in 1900 without any experience in teaching, County Superintendent E. J. Hook of Winneshiek County commented in 1901 that it was "fair to presume" that 99 percent of these teachers "taught their first term in the rural schools. ${ }^{\pi 39}$

There were good teachers in the country schools, to be sure. Although generally critical of rural teaching, State Superintendent John Riggs admitted that some of the best teachers in the state taught in the country schools. County Superintendent Bertha Howard of Clarke County believed that the good rural teachers acted as a leaven. "The results obtained by the best teachers in our rural schools are such as to justify the assertion that the greatest need of our schools at the present time is a full corps of really competent instructors," Howard declared. Better teachers were the key to better schools. County Superintendent F. M. Witter of Muscatine County, president of the ISTA in 1903, thought that many rural teachers turned out to be better teachers than might be expected from their meager preparation. Witter estimated that more than half of Iowa's rural teachers had received no education or training beyond the common country schools they had attended. "They have had absolutely no training for their work, have never read a book or paper relating to the business in which they are engaged," Witter observed. One would naturally assume that children would learn little from such novices, said Witter, but he had found, to his surprise, "some good work done in almost every school, and in many the true spirit of the teacher exists in a marked degree." If allowances were made for their lack of preparation, Witter thought that the work of teachers in the country, taken as a group, compared favorably to that of teachers in the city. ${ }^{40}$

The shortage of skilled teachers in Iowa reflected the transient character of teaching at the time. Deficient in money, power, status, and security, teaching did not hold out the rewards that were necessary to induce ambitious young men and

39. Ibid., 1902, 3: 17, 31; ISTA, Proceedings, 1901, 75.

40. IaDPI, Report, in Ia Leg Doc, 1906, vol. 5, pt. 2, 117-18; ibid., 1902, 3: 290; ISTA, Proceedings, 1903, 30. 
women to make a career of teaching. Most teachers regarded teaching as a stepping stone, a temporary occupation to be pursued only until they were able to find something better. The number of new recruits entering the ranks of Iowa's teaching force each year made up about one-fifth of the total number, resulting in an almost complete turnover of teachers every four or five years. "The greatest needs of the schools are more teachers who are thoroughly prepared for their work," reported County Superintendent Arthur Farquhar of Audubon County. "Twenty per cent of the experienced teachers quit the work each year and their places must be filled by those who have had no experience and little or no preparation for teaching." 41

Educators warned that Iowa's dependence on inexperienced teachers seriously weakened the state's public school system. "In no other department of human activity is the raw recruit, or short term employee, regarded as desirable," commented Eugene Secor, a member of the Forest City school board. "The ability which comes only from long and continuous service is valued and sought after." "The schools are greatly crippled because of the young army of inexperienced teachers that come in the school room every year," observed County Superintendent Anna White of Jefferson County. The "one great drawback" of the teaching profession, complained County Superintendent P. O. Cole of Cerro Gordo County, was the "constant" change of teachers from year to year. More than thirty of the two hundred applicants for certification in Cerro Gordo County in the fall of 1900 were inexperienced and untrained "beginners" who must "necessarily go out to experiment upon the innocent youth," but this could not be helped, said Cole, because the beginners were needed to replace experienced teachers who had abandoned teaching. ${ }^{42}$

Teachers dropped out of teaching for a variety of reasons. Many female teachers opted for marriage. One of the few professions open to women at the time, teaching in Iowa as in other states had become largely a feminine occupation by 1900 . Of the 24,657 certificates issued by the county superintendents of Iowa

41. ISTA, Proceedings, 1900, 99-100; ibid., 1901, 26; ibid., 1903, 22-23; ibid., 1905, 62; IaDPI, Report, in Ia Leg Doc, 1902, 3: 281.

42. ISTA, Proceedings, 1900, 100; IaDPI, Report, in Ia Leg Doc, 1902, 3: $289,307$. 
in $1900,20,703$ were issued to women and 3,954 to men. County Superintendent Clarence Messer of Humboldt County could have been speaking for many of the county superintendents of Iowa when he said that the majority of the teachers in Humboldt County were "earnest, conscientious" young women who taught about three years and then married well-to-do farmers. ${ }^{43}$

Many teachers gave up teaching because of its chronic insecurity. Teachers were always exposed to the dictates of school boards and the vagaries of popular opinion. Tenure was uncertain; teaching contracts generally ran no longer than a year with no certainty of renewal. Boards of directors in many rural districts hired teachers for only one or two terms, an unsettling practice for teachers and pupils alike, since a school might have a different teacher each of the three terms of the school year-fall, winter, and spring. Of 10,053 one-room rural schools in Iowa reporting for the school year 1903-4 (out of a total of 12,521 such schools), only 3,409 (34 percent) employed the same teacher throughout the school year. Of the remaining schools, 4,836 (48 percent) employed two different teachers during the year, while 1,808 (18 percent) hired three different teachers during the year. ${ }^{44}$

Urban school boards generally employed teachers for the full school year and reemployed those who were successful. Even in the cities, however, teachers did not enjoy the "feeling of permanency which promises well for the profession or the school interests of Iowa," opined Eugene Secor, a director of the Forest City schools. State Superintendent Barrett found "quite general unrest" among teachers, principals, and superintendents, especially those in cities and towns, over a decision by the $14-15$

43. IaDPI, Report, in Ia Leg Doc, 1902, 3: 304, Appendix, "Abstract [C],"

44. ISTA, Proceedings, 1899, 129-30; IaDPI, Report, in Ia Leg Doc, 1906, vol. 5 , pt. $1,83-84$, pt. $2,95,112$. In a circular issued to local school boards on February 14, 1905, State Superintendent John Riggs noted that the contracts of several thousand rural teachers had expired or were about to expire. He urged that those who had been competent and successful be reappointed for the spring term and that beginning with the fall term, 1905-6, teachers who were known to be capable be hired for the entire school year instead of for one or two terms. "A more permanent tenure for teachers and good salaries for good teachers is [sic] one of the crying needs of our schools," Riggs declared. IaDPI, Report, in Ia Leg Doc, 1906, vol. 5, pt. 1,83-84. 
Supreme Court of Iowa that the laws of the state did not allow school boards to employ teachers for more than a single year at any one time. Noting that six hundred men had given up teaching in Iowa during the school year, 1899-1900, and that the number of male teachers in the state had dropped from 39 percent of the total in 1870 to 20 percent in 1899, Barrett suggested that the insecurity inherent in brief tenure was a major reason so many men had quit teaching in Iowa. "Many men occupying positions considered among the best have voluntarily abandoned teaching, in part, because of the short term of service for which contracts may be drawn," declared Barrett. ${ }^{45}$

Iowa teachers were not only vulnerable and insecure; they were also poorly paid. Calculating the average annual salaries of teachers in Iowa in 1903 to be about four hundred dollars for men and less than three hundred for women, the Educational Council, the policy-making body of the ISTA, stated that teachers, male or female, could not support themselves, let alone families, on such meager incomes. "When it is considered that the commonest unskilled laborer receives an annual wage of from $\$ 450$ to $\$ 700$, the absurdity of this pay for teachers, who have spent much time and money in preparation for their work, becomes painfully apparent," declared the Educational Council. ${ }^{46}$

Utilizing the Report of the United States Commissioner of Education for 1902, the Educational Council noted that the salaries of Iowa teachers were among the lowest in the nation. In salaries paid to male and female teachers, Iowa stood twentyseventh and thirty-fifth respectively among the forty-five states. In total average salaries paid to teachers of both sexes, Iowa ranked thirty-first nationally. Even more embarrassing than Iowa's low national standing in teachers' salaries was the state's low regional ranking; Iowa teachers generally were paid less than their colleagues in surrounding states. Among the twelve states of the North Central division, Iowa ranked eighth in average monthly salaries paid to female teachers, and was tied with South Dakota for last place in average monthly salaries paid to teachers of both sexes. ${ }^{47}$

45. ISTA, Proceedings, 1900, 100; IaDPI, Report, in Ia Leg Doc, 1902, 3: 16-17; ibid., 1906, vol. 5, pt. 1, 14-15, pt. 2, 118.

46. ISTA, Proceedings, 1899, 186; ibid., 1903, 18.

47. Ibid., 1903, 16, 17. Average monthly teachers' salaries in Iowa in 
IOWA'S POORSHOWING in teachers' salaries was not due to the refusal of Iowans to support public education but rather to an outmoded and inefficient system of school organization, which saddled the state with too many school districts and too many teachers. Iowa ranked relatively high among the states in school expenditures but stood even higher in number of teachers employed. Compared to the six New England states, the three northeastern states of New York, New Jersey, and Pennsylvania, and the twelve states of the North Central division, twenty-one states in all, Iowa ranked fifth and sixth, respectively, in the amount of money raised for school purposes per adult male citizen and in the amount raised for each person of school age (those five to eighteen years old). In total numbers of teachers employed, however, lowa was third among the twenty-one states with 29,073 teachers, following New York $(36,636)$ and Pennsylvania $(30,640)$ and running ahead of such populous states as Illinois $(27,186)$, Ohio $(26,410)$, and Massachusetts $(13,622) .48$

The disproportionately high number of teachers in Iowa was due to "lack of adaptation and economical management," said the Educational Council; Iowans failed to reorganize their school system in accordance with the turbulent economic and social changes that were sweeping across America at the turn of the century. Iowans had done a great deal of tinkering with their schools but had not remodeled the school system as a whole since its inception. The organic education law of 1858, "An Act for the public instruction of the state of lowa," laid out the framework of a statewide system of public education extending from the elementary grades to the state university. It changed the traditional method of organizing Iowa's school districts by reorganizing the original independent districts into district townships.

1902 were $\$ 44$ for males and $\$ 30$ for females; national averages were $\$ 49$ for males and $\$ 40$ for females. In the North Central States average monthly salaries were $\$ 59$ in Illinois, $\$ 57$ in Indiana, $\$ 46$ in Wisconsin, $\$ 45$ in Minnesota, $\$ 44$ in Nebraska, $\$ 43$ in Missouri, $\$ 40$ in Kansas and North Dakota, \$39 in Ohio, and $\$ 37$ in South Dakota and Iowa. The average annual salary of teachers, superintendents, and supervisors in lowa cities of more than eight thousand people was $\$ 471$, placing Iowa thirty-third nationally in that category. Ibid., 16, 17.

48. Ibid., 17, 18. 
Excluding only incorporated cities and towns of more than one thousand people, which were to be separate districts, the act of 1858 declared all civil townships in the state to be school districts and made all existing independent districts subdistricts of the district townships. ${ }^{49}$

Control of the district township schools was vested in the townships subject to the supervision of the county superintendents and the state superintendent of public instruction. At the annual meeting of the district township, voters determined fiscal policy, deciding how to raise the township's share of the money needed to establish, maintain, and operate the district's schools. The voters might also decide whether schools "of a higher grade" ought to be established in the district, a provision signaling the beginning of public high schools in Iowa. And the voters might, if they wished, delegate their powers to the district township board of directors. ${ }^{50}$

Charged with oversight of the schools, the board of directors comprised a president, vice-president, and secretary elected at large at the annual meeting of the district's voters plus directors elected by the subdistrict voters, one director for each subdistrict. In addition to implementing the decisions of the annual meeting, the directors were to decide how many schools were to be established in the district and how long they were to be in session subject to the law's requirement that all public schools in the state must be in session at least sixteen weeks each year; to employ teachers, hiring only those whose qualifications to teach had been certified by the county superintendent; to decide what subjects were to be taught; and to visit schools to assist the teachers in establishing and enforcing rules for the "government" of the schools, in keeping correct pupil records, and in such other matters as the directors considered necessary to promote the schools' welfare. The directors could change the boundaries of existing subdistricts and establish new subdistricts as needed. If the directors felt that the schoolhouse tax levied by the annual meeting fell unequally on

49. Ibid., 17; IaDPI, Report, in Ia Leg Doc, 1900, 2: 16-17; Laws of Iowa, 1858, 57; Clarence Ray Aurner, History of Education in Iowa, 5 vols. (Iowa City, 1914-1920), 1: 49-79.

50. Laws of Iowa, $1858,59-61,73-80$. 
the subdistricts, they could equalize the tax according to the needs and resources of the subdistricts. ${ }^{51}$

The act of 1858 was an uncertain mixture of new principles and old practices, an uneasy compromise between the growing need to unify and coordinate administration of the schools and the traditional emphasis on decentralization of school organization and management. Judging by the broad powers conferred on the district township authorities, the General Assembly intended that the district township constitute a unit operating under the central direction of the annual meeting and the board of directors. However, the legislators largely vitiated the unitary concept by perpetuating the original district structure, by incorporating existing districts into the townships and dividing power between the two. The act of 1858 provided that members of the township board of directors elected by the subdistricts were to supervise the upkeep and operation of the subdistrict schools and might also employ teachers with the approval of the township board. The law evidently intended that the subdistrict directors act under the authority of the township board, but the township board's oversight was of ten nominal rather than real. In practice, therefore, the subdistricts tended to run their schools as they saw fit, and the change from independent district to subdistrict was little more than a change in name. ${ }^{52}$

The act of 1858 set the stage for a debate over the township versus the independent district method of school organization that carried over into the twentieth-century struggle over consolidation. Professional opinion generally favored a unitary township plan, believing that bigger and stronger districts were necessary to achieve better schools. Successive state superintendents of public instruction agreed that a system of undivided school townships would be more efficient, more economical, and more equitable than an independent district system. Superintendent A. S. Kissell (1869-1872), for example, said that "a large majority of the most active friends of education in Iowa" had always "insisted" that the division of the district townships into subdistricts was a "serious mistake"; it would have been much better to have made each civil township into a "simple,

51. Ibid., 59-69.

52. Ibid., 68; IaDPI, Report, in Ia Leg Doc, 1900, 2: 78. 
single" school district governed by a board of directors elected at large. Superintendent C. W. von Coelln (1876-1881) agreed that the civil township ought to be the unit of school organization, particularly in rural areas. "The objections to the division into rural independent districts are, a needless multiplication of officers, for which often suitable persons cannot be found, the unnecessary expense of paying so many secretaries and treasurers, and the inability of many of these districts to provide proper school facilities, owing to the lack of means," von Coelln stated. Summarizing the case for the township system, Superintendent Barrett noted that a civil township generally was bigger than a district, tending thereby to distribute the costs and opportunities of public education more equally and to provide better schools more economically than the district. ${ }^{53}$

The proponents of district township units were ahead of their time, however, and their arguments were largely unheeded by the public. Most Iowans were deeply attached by conviction, convenience, and custom to the traditional system of independent districts and neighborhood schools. They believed that local organization and control of education was an integral part of local self-government and the democratic process. Some Iowans even regarded supervision of the schools by county superintendents as unwarranted outside interference with their democratic prerogatives. "A school house within easy walking distance of every dwelling in the state has always been a popular doctrine with the people," observed State Superintendent John F. Riggs. "A square containing just four sections, with nine of these squares in a civil township, and each square a little school world in itself, has to the popular mind seemed so ideal that any interference with the established order has always raised bitter opposition." "Iowa, like other states, has suffered in a sense from too much democracy," Principal W. O. Riddell of Des Moines West declared in his presidential address to the ISTA in 1900. "How else can we account for the persistency with which we adhere to the wasteful, ineffective, almost pernicious, sub-district system. ${ }^{54}$

53. IaDPI, Report, in Ia Leg Doc, 1900, 2: 73-79; ibid., 1906, vol. 5, pt. 1, $20-23$.

54. Ibid., 1906, vol. 5, pt. 1, 20; ISTA, Proceedings, 1900, 17; Aurner, Education in Iowa, 1: 235-78, 2: 64-92; Jay J. Sherman, "History of the Office of 
The growth of schools in Iowa after the Civil War confirmed the critics' worst fears regarding the proliferation of independent districts and subdistricts and the harmful consequences thereof. During the thirty years between 1870 and 1900 , when the settlement of Iowa was largely completed, the number of district townships in the state increased only slightly, from 1,176 to 1,187 , while the number of independent districts jumped from 334 to 3,686 and the number of subdistricts from 6,986 to 9,423 . A large number of the independent districts and subdistricts were small rural units serving a handful of farm families. Attendance at rural schools averaged about fifteen pupils per school. In 1899 , for example, average daily attendance in 1,950 rural independent districts and 7,379 rural subdistricts, comprising 53 percent and 79 percent respectively of the whole number of independent districts and subdistricts in the state, was fewer than twenty pupils. Average daily attendance in 70 of the independent districts and 263 of the subdistricts was fewer than five pupils; in 502 independent districts and 2,075 subdistricts, fewer than ten; and in 1,273 independent districts and 5,100 subdistricts, fewer than fifteen. ${ }^{55}$

Iowa educators agreed that the independent district system was the immediate cause of the poor quality of education in much of rural lowa. "That our present system of small districts is usually extravagant and is often the direct cause of inefficient schools cannot be questioned by anyone who will give thorough study to the question," State Superintendent John Riggs observed in 1905. Riggs and others pointed out that the rapid multiplication of districts and subdistricts had resulted inevitably in the creation of school units that were too small in area and too limited in resources to support good schools without resorting to excessive taxation. Unable to pay high enough salaries to employ qualified teachers, the small districts were often forced to hire poorly prepared teachers at low salaries. It was the low sala-

County Superintendent of Schools in Iowa," Iowa Journal of History and Politics 21 (January 1923), 12-14, 20-21, 28-31, 35, 37-38, 47-48; idem, "The County Superintendent of Schools," in Benjamin F. Shambaugh, ed., Applied History, vol. 4, County Government and Administration in Iowa (Iowa City, 1925), 296.

55. IaDPI, Report, in Ia Leg Doc, 1900, 2: 69-70, 80-81; ibid., 1902, Appendix, 468-69; ISTA, Proceedings, 1900, 71. 
ries of rural teachers that caused Iowa's poor showing in comparative teachers' salaries; the median monthly salaries of rural teachers in Iowa during the school year, 1903-4, for example, were thirty dollars for the fall and spring terms and thirty-five dollars for the winter term. "The number of inexperienced teachers would not be so great if it were not for the great number of small schools and the difficulty of securing teachers for them," State Superintendent Richard Barrett reported. "If the standard of teaching in hundreds and hundreds of districts was not necessarily very low, it would be impossible for so many persons to secure employment as teachers without any preparation whatever for their work beyond what they have secured in the common schools." 56

Conditions in small country schools often placed both children and teachers at a disadvantage. Classes were small, frequently consisting of only one or two pupils, so that children had little opportunity to learn from one another and little incentive to excel through competition with one another. Faced with responsibility for teaching the whole curriculum and the need to divide their time and attention among all classes in six to eight grades, even the best teachers were hard pressed to classify their students and to systematize their work. "The teacher's time is so cut up and spread out over a great number of subjects that it is impossible for her to do her best work in any of them and the interest of teacher and pupil is likely to lag," commented State Superintendent Barrett. There were "thousands" of rural school districts in lowa where such conditions "are almost certain to prevail for many years to come" because the districts were too weak to support strong schools, Barrett stated. The only solution to this problem, said Barrett, was to consolidate weak districts into one strong district and to transport children to a central school at the expense of the consolidated district. ${ }^{57}$

Barrett's proposal to consolidate schools was a sign of the times. Public opinion was not yet ready for consolidation, but leading educators realized that the times called for a reorganization of the school system into larger units. They saw that the problems of rural education resulted from the operation of long-

56. IaDPI, Report, in Ia Leg Doc, 1906, vol. 5, pt. 1, 20, pt. 2, 110-11; ibid., 1902, 3: 31 .

57. Ibid., 1902, 3: 32, 34. 
range economic and social forces that were here to stay: the growth of manufacturing, the shift of population from the country to the city, the mechanization of agriculture, and the trend toward bigger farms. Educators were coming to realize that education, like agriculture, labor, manufacturing, transportation, and other segments of American society, must consolidate if schools were to meet the demands and reap the benefits of industrialism. "We live in an age of consolidation and cooperation," State Superintendent Riggs told the ISTA in 1904. "Your effort united with mine multiplies the power of us both. In this age no man liveth unto himself." The twentieth century was at hand. Consolidation was the order of the day. ${ }^{58}$

58. Ibid., 1906, vol. 5, pt. 2, 120-23. 
Copyright of Annals of Iowa is the property of State of Iowa, by \& through the State Historical Society of Iowa and its content may not be copied or emailed to multiple sites or posted to a listserv without the copyright holder's express written permission. However, users may print, download, or email articles for individual use. 